\title{
Hydrocarbon generation modeling and source rock characterization of the Cretaceous-Paleocene Taratu Formation, Great South Basin, New Zealand
}

\author{
Liyana Nadiah Osli ${ }^{1} \cdot$ Mohamed R. Shalaby ${ }^{1} \cdot$ Md. Aminul Islam ${ }^{1}$
}

Received: 20 February 2018 / Accepted: 17 June 2018 / Published online: 25 June 2018

(c) The Author(s) 2018

\begin{abstract}
Hydrocarbon generation modeling and source rock characterization have been carried out on rock samples of the Taratu Formation in the Great South Basin, New Zealand. The Paleocene and Late Cretaceous Taratu Formation samples from Tara-1 well are utilized for geochemical studies. Rock-Eval pyrolysis results show that Taratu formation accommodates organic matter of excellent quantity and quality, with proliferous kerogen type II-III (oil and gas prone) and minor kerogen type III (gas prone). Hydrogen index (HI) of this formation ranges from 165.0 to $327.5 \mathrm{mg} \mathrm{HC} / \mathrm{g}$ TOC and only Late Cretaceous source rock samples are thermally mature, with maximum pyrolysis temperature $\left(T_{\max }\right)$ up to $459^{\circ} \mathrm{C}$ and vitrinite reflectance $\left(\% R_{\mathrm{o}}\right.$ ) from 0.40 to $1.15 \% R_{\mathrm{o}}$. One-dimensional basin modeling shows a best fit in a calibration of measured and modeled temperatures and vitrinite reflectance. The top of oil window was encountered $51 \mathrm{Ma}$ ago at $3100 \mathrm{~m}$ and gas generation took place at $4132 \mathrm{~m}$ in $8 \mathrm{Ma}$ ago.
\end{abstract}

Keywords Taratu Formation · Source rock characterization · Burial history modeling · Great South Basin · New Zealand

\section{Introduction}

The area of study is located to the south of the South Island, Great South Basin in New Zealand. The Great South Basin (GSB) is the largest deepwater basin in the Campbell Plateau (Fig. 1), with dimensions extending approximately up to an area of 100,000 km² (Evans 1982; Killops et al. 1997). This basin comprises primarily grabens and half-grabens, containing sediments from the Late Cretaceous to Early Tertiary (Schiøler et al. 2009; Evans 1982; Beggs 1993; Cook et al. 1999). Based on hydrocarbon potential studies undergone by Killops et al. (1997), Cook et al. (1999), and Constable et al. (2013), this basin is found to contain promising source rocks despite not having a commercial hydrocarbon production and limited exploration. Hydrocarbon-bearing formations in this basin are mainly coals and black marine shales from

Mohamed R. Shalaby

mshalaby2004@yahoo.com

1 Department of Physical and Geological Sciences, Faculty of Science, Universiti Brunei Darussalam, Jalan Tungku Link, Bandar Seri Begawan BE1410, Brunei
Cretaceous and Paleocene (Uruski and Baillie 2001; New Zealand Petroleum and Minerals 2014).

The Taratu Formation is important for the complete petroleum system in the Great South Basin (Killops et al. 1997) and was previously studied by Killops et al. (1997, 2001, 2008) as well as Sykes et al. (1998). It is characterized by cross-bedded pebble conglomerate, sandstones, shale, and coal measures with carbonaceous siltstone (McMillan and Wilson 1997). There is an abundance of vein quartz that later becomes the source of the Haast Schist (Aitchison et al. 1993). Coals of this formation are lignite to sub-bituminous. Fine-to-coarse-grained sandstones, which make up the reservoir unit of this formation, are also present. The Taratu Formation was subjected to marine influence and the coals are produced by brackish water (Raine et al. 1993; Wilson and McMillan 1996).

From the 1970s to the present, only eight wells have been drilled in the Great South Basin, four of which displayed an affirmative response for the presence of hydrocarbon (New Zealand Petroleum and Minerals 2014). Wells that encountered gas condensates in Cretaceous Formations are Kawau-1A, Toroa-1, and Pakaha-1 wells, with minor methane detected in Pukaki-1 well. Takapu-1 and Rakiura-1 wells failed to record the presence of hydrocarbon. Two source 


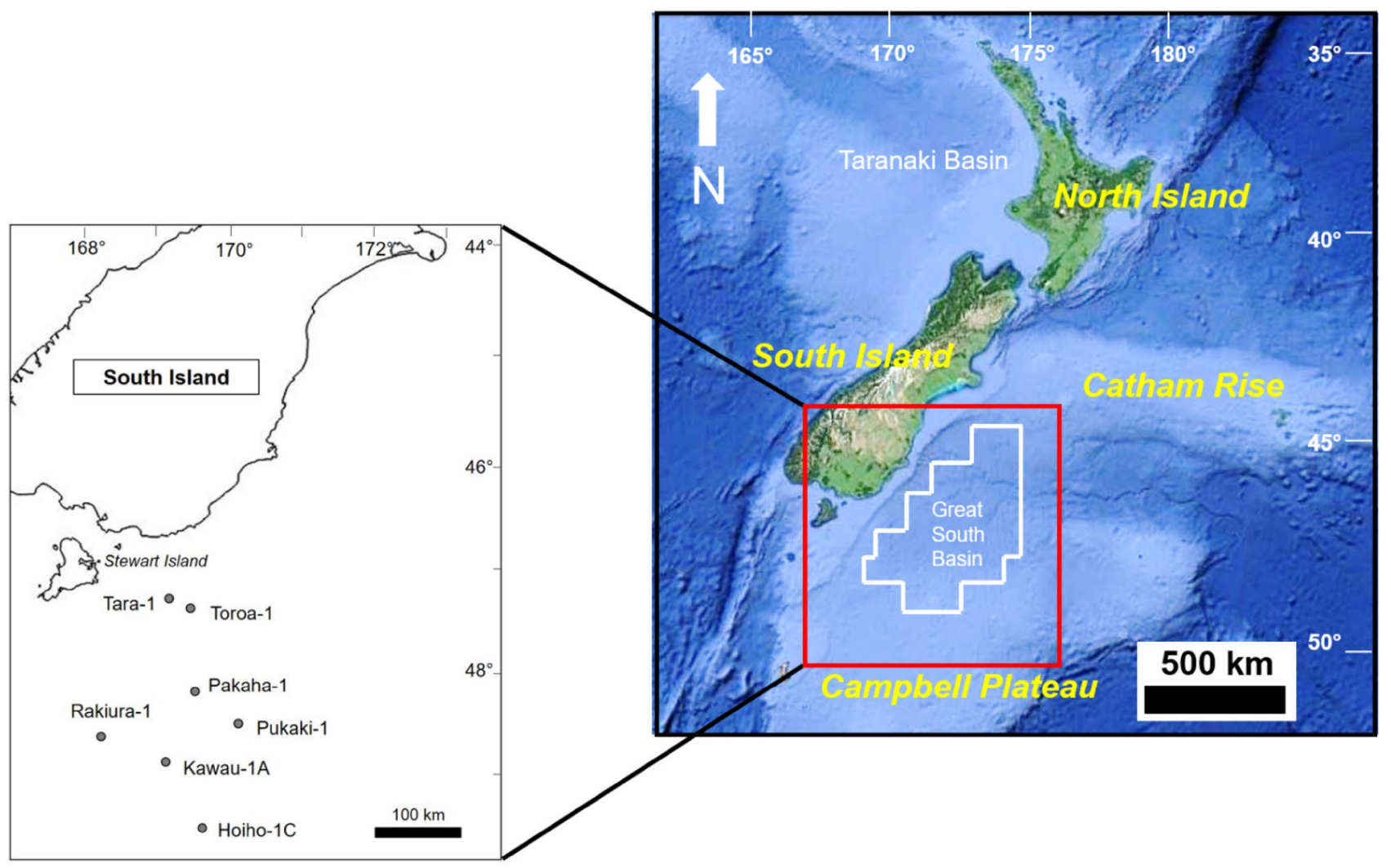

Fig. 1 Map of New Zealand with locations of the Great South Basin and study area. Modified after Schiøler et al. (2009)

rocks are detected in Hoiho-1C well, but no hydrocarbon show is recorded in those rocks.

The main objective of this study is to evaluate the Taratu Formation using geochemical data to assess the organic matter quality, quantity, and hydrocarbon generation potential. Various techniques of assessing a source rock as performed by Shalaby et al. (2011), Qadri et al. (2016) and Jumat et al. $(2017,2018)$ have been referred to in this research. Following geochemical analysis, this study also constructs a onedimensional basin model using stratigraphic, temperature, and vitrinite reflectance data to investigate the exact timing and depth of hydrocarbon generation windows for the Taratu Formation.

\section{Geological setting and stratigraphy}

Schiøler et al. (2009), McMillan and Wilson (1997), and Constable et al. (2013) have studied on the Great South Basin's stratigraphy and geological settings. Major tectonic activities that led to the formation of the Great South Basin began in the Cretaceous (New Zealand Petroleum and Minerals 2014). The convergent tectonic regime in the eastern margin of New Zealand began to shift into an extensional pattern at this period. Phoenix Plate was no longer subducted at 105-100 Ma and rifting began, causing the separation of New Zealand from Gondwana (Laird and Bradshaw 2004). As a result, a global uplifting and erosion of land occurred, leading to the formation of the Albian Unconformity that affected New Zealand. New Zealand was completely separated from the east of Gondwana in the Late Cretaceous, and this phenomenon was represented by widespread marine transgression that peaked in Oligocene, which eventually led to the formation of the Tasman Sea (Laird and Bradshaw 2004).

Rifting in the Great South Basin completely halted in the Late Cretaceous and was succeeded by thermal subsidence that continued until the Paleogene (Constable et al. 2013). At this time, transgressive marine sediments that include sandstone, greensand, and mudstone were deposited (Fig. 2). Further subsidence of the basin led to the deposition of carbonates and calcareous mudstone (Killops et al. 1997; New Zealand Petroleum and Minerals 2014).

At the western margin of the Great South Basin, a prograding delta which was initiated by thermal subsidence was formed in the Paleocene. Sediment supply to this delta halted following the final opening of the Solander and Emerald sub-basins. This margin was also heavily affected by tectonic activities in Oligocene-Miocene (King 2000; Constable et al. 2013). 


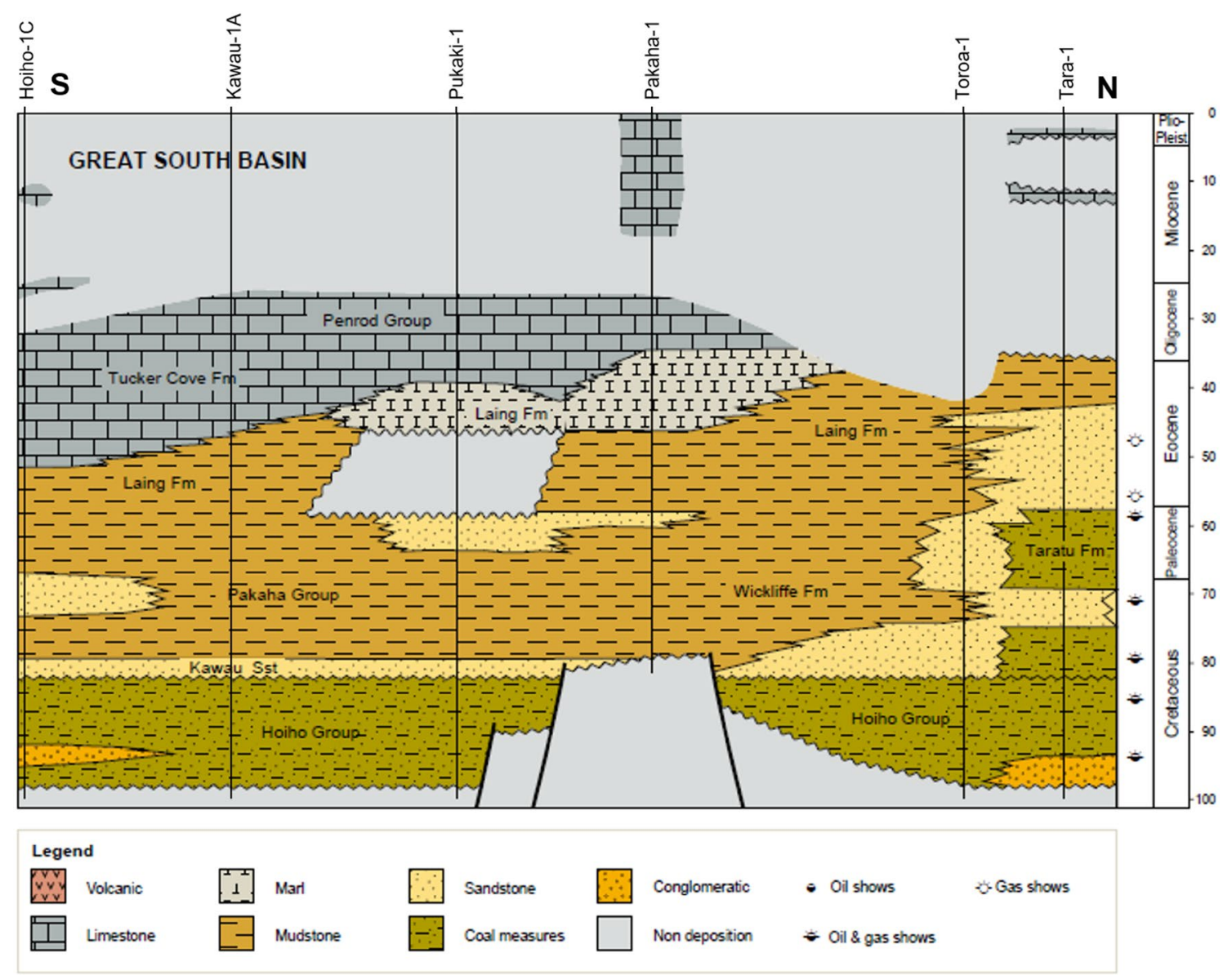

Fig. 2 Stratigraphy of the Great South Basin. Modified after New Zealand Petroleum and Minerals (2014)

Due to the ongoing compressional stresses from the orogeny along the Alpine Fault in the Miocene, the western margin of the Great South Basin was folded into anticlines and synclines, therefore causing this part of New Zealand to be uplifted (New Zealand Petroleum and Minerals 2014). As a result, a thick sequence illustrating marine progression is located at the western margin of the basin that trends north east (Laird and Bradshaw 2004; Schiøler et al. 2009). In Neogene, pelagic sediments began to accumulate on the eastern part of the Great South Basin (Killops et al. 1997).

Upon the initiation of rifting in Mid-Cretaceous, grabens and half-grabens that are oriented in the NW-SE directions are formed, which later accumulated sediments (Constable et al. 2013). Conglomerates, sandstones, mudstones, and coal from fluvial and lacustrine environments fill up these grabens to make up the Hoiho Formation and rests unconformably on the basement rocks of the Great South Basin (Fig. 2; Laird and Bradshaw 2004; Constable et al. 2013; New Zealand Petroleum and Minerals 2014).

The Hoiho Group is overlain by the Pakaha Group, which is formed by the deposition of fine-grained marine siliciclastics in the Late Cretaceous to Paleocene. Transgressive sandstones of the Kawau Formation makes up the base of the Pakaha Group, which is overlain by the Wickliffe Formation (Fig. 2). Sandstones of the Taratu Formation in turn overlie the Kawau sandstones (Schiøler et al. 2009).

The Taratu Formation comprises quartzose grit, conglomerates, sandstone, and shales with coal measures (Fig. 2). Coals of this formation were deposited in brackish water as it has been subjected to marine influence (Raine et al. 1993; Wilson and McMillan 1996).

\section{Data and methods}

The Ministry of Business, Innovation and Employment (MBIE) of New Zealand and GNS Science have provided and permitted the usage of all data for this study. A total of 32 drill cutting samples from Tara- 1 well from depths 2225 to $4109 \mathrm{~m}$ are utilized for geochemical analyses. Taratu Formation rock samples belong to two different ages; from Late Cretaceous to Paleocene, with the Paleocene Taratu Formation encountered at depths shallower than $2700 \mathrm{~m}$, while the 
formation at greater depth belongs to Late Cretaceous. The observed lithology in this formation is coal and mudstone.

Source rock evaluation through pyrolysis using RockEval 2 that serves as the main focus in this study involves assessing the source rock maturity, type of organic matter, hydrocarbon generation, burial, and thermal histories of the Taratu source rock. To achieve this, Rock-Eval pyrolysis results such as volume of free hydrocarbon generated before pyrolysis $\left(S_{1}\right)$, amount of hydrocarbon generated during pyrolysis $\left(S_{2}\right)$, amount of carbon dioxide emitted $\left(S_{3}\right)$, total organic carbon (TOC), and maximum pyrolysis temperature $\left(T_{\max }\right)$ are used. Derivations of these parameters are also important to utilize to evaluate the source rock. Such indices include hydrogen index $\left(\mathrm{HI}=S_{2} / \mathrm{TOC} \times 100\right)$, oxygen index $\left(\mathrm{OI}=S_{3} / \mathrm{TOC} \times 100\right)$, production yield $\left(\mathrm{PY}=S_{1}+S_{2}\right)$, production index ( $\left.\mathrm{PI}=S_{1} / S_{1}+S_{2}\right)$, and $S_{2} / S_{3}$ (Tissot and Welte 1984; Peters 1986; Mukhopadhyay 1994).

Sea water was used as the drilling mud in this study. Drill cuttings are collected from the shaker screen and washed through a 2-mm sieve using fresh water to eliminate mudcakes and small-sized particles. No organic solvents are used to avoid removal of soluble constituents. Samples to be analyzed are then air-dried at $40{ }^{\circ} \mathrm{C}$ and should be weighed to $50 \mathrm{~g}$ prior to commencing any analysis.

Vitrinite reflectance $\left(\% R_{\mathrm{o}}\right)$ as a maturity indicator has been determined for a total of 28 samples. Analysis of vitrinite reflectance has been carried out on ditch cuttings at two to four hundred feet intervals. Vitrinite reflectance was measured according to ASTM (1975) standard, in which a sample was made into two pellets and 200 point counts are required for one pellet. Mean values of the counts are then calculated to obtain the vitrinite reflectance values.

One-dimensional basin model is generated using the PetroMod software (version 9.0) to analyze the burial and thermal maturity histories for the Taratu Formation. All parameters mandatory for basin modeling are prepared for the well under study, including name of formations as detected in the well, formation age (Ma), formation thickness (m), measured borehole temperature (celsius), and measured vitrinite reflectance $\left(\% R_{\mathrm{o}}\right)$. This research uses a constant heat flow of a constant heat flow of $60 \mathrm{~mW} / \mathrm{m}^{2}$ (Godfrey et al. 2001) and a kinetic model introduced by Pepper and Corvi (1995). This model suggests that the central parameter that controls expulsion of hydrocarbon is the hydrogen index of the formation and applies five organofacies in characterizing a source rock. This study applies the kinetic model type III DE for the source rock of study because this model type is suitable for terrigenous, non-marine, and waxy source rock, such as the Taratu Formation. In this study, kinetic model type III DE is applied for the source rock of study as the Taratu Formation. A water depth of $123.4 \mathrm{~m}$ beneath sea level is another boundary condition in 1-D modeling. Petroleum system elements that each formation represents together with other relevant geochemical parameters belonging to the studied source rock such as TOC and HI are also useful.

In logging operations, bottomhole temperature is often documented before equilibrium between the formation and drilling mud temperatures is reached. Therefore, temperature values extracted from composite logs must be corrected prior to calibration. Correction of borehole temperatures in this study has been carried out based on studies by Waples and Ramly (1994, 2001), Peters and Nelson (2012) and Bullard (1947).

\section{Results and discussion}

\section{TOC and Rock-Eval pyrolysis results}

The $S_{1}$ peak indicates the amount of existing hydrocarbon that is easily discharged during pyrolysis. More kerogen is broken down with further thermal degradation of source rock, which is illustrated in the $S_{2}$ readings. In this research, $S_{1}$ values obtained range from 3.6 to $21.4 \mathrm{mg} \mathrm{HC} / \mathrm{g}$ rock, indicating very good results. Values ranging from 31.8 to $200.4 \mathrm{mg} \mathrm{HC} / \mathrm{g}$ rock are obtained for $S_{2}$ and the $S_{3}$ peak contain readings from 2.3 to $16.4 \mathrm{mg} \mathrm{HC} / \mathrm{g}$ rock. The Taratu source rock comprises TOC readings that range from 23 to $89 \%$; therefore, the source rock is considered to have excellent quantity based on the classification introduced by Peters (1986).

$\mathrm{OI}$ and $\mathrm{HI}$ are the most important parameters that can be correlated together to do kerogen typing of source rocks. OI and $\mathrm{HI}$ as calculated for the Taratu source rock ranges from 5.00 to $25.7 \mathrm{mg} \mathrm{CO}_{2} / \mathrm{g}$ TOC and 165.0 to $327.5 \mathrm{mg} \mathrm{HC} / \mathrm{g}$ TOC respectively. The ratio between $S_{2}$ and $S_{3}$ is another index that can be applied in the classification of kerogen and has values from 7.69 to 38.0. A complete record of the aforementioned parameters is listed in Table 1.

A classification of hydrocarbon generation windows by $T_{\max }$ values has been done by Peters and Cassa (1994). In this classification, the mature oil window is encountered at a $T_{\max }$ range of $435-450{ }^{\circ} \mathrm{C}$; any lower temperature below $435{ }^{\circ} \mathrm{C}$ indicates that a source rock is thermally immature and $T_{\max }$ values above $470{ }^{\circ} \mathrm{C}$ is indicative of a thermally over-mature source rock. This classification also states that the gas window of a source rock is reached at $T_{\max }$ values of $450-470{ }^{\circ} \mathrm{C} . \mathrm{T}_{\max }$ values of this study ranges from 420 to $459{ }^{\circ} \mathrm{C}$, which differs between the Paleocene and Late Cretaceous source rocks, making it a useful index to measure thermal maturity that might vary for organic matter with different ages.

Vitrinite reflectance $\left(\% R_{\mathrm{o}}\right)$ is a good parameter that is applicable in the evaluation of source rock thermal maturity. The Taratu source rock records vitrinite reflectance 
Table 1 Results of Rock-Eval pyrolysis from Tara-1 well used in this study

\begin{tabular}{|c|c|c|c|c|c|c|c|c|c|c|c|}
\hline Depth (m) & Lithology & $S_{1}$ & $S_{2}$ & $S_{3}$ & TOC & OI & $\mathrm{HI}$ & PI & $S_{2} / S_{3}$ & $\mathrm{PY}=S_{1}+S_{2}$ & $T_{\max }$ \\
\hline \multirow[t]{2}{*}{2225} & Coal & 8.00 & 117 & 15.0 & 58.3 & 25.7 & 200 & 0.06 & 7.78 & 125 & 421 \\
\hline & Mudstone & 3.60 & 54.2 & 6.80 & 29.5 & 23.1 & 184 & 0.06 & 7.97 & 57.8 & 423 \\
\hline \multirow[t]{2}{*}{2344} & Coal & 13.2 & 148 & 13.4 & 64.6 & 20.7 & 230 & 0.08 & 11.1 & 162 & 420 \\
\hline & Mudstone & 8.70 & 120 & 8.60 & 45.5 & 18.9 & 263 & 0.07 & 13.9 & 129 & 423 \\
\hline \multirow[t]{2}{*}{2509} & Coal & 20.1 & 162 & 11.9 & 62.4 & 19.1 & 260 & 0.11 & 13.6 & 182 & 423 \\
\hline & Mudstone & 7.80 & 89.6 & 5.80 & 29.2 & 19.9 & 307 & 0.08 & 15.4 & 97.4 & 426 \\
\hline \multirow[t]{2}{*}{2719} & Coal & 12.6 & 153 & 12.5 & 63.7 & 19.6 & 240 & 0.08 & 12.2 & 165 & 429 \\
\hline & Mudstone & 5.90 & 82.9 & 5.60 & 26.0 & 21.5 & 319 & 0.07 & 14.8 & 88.8 & 429 \\
\hline 2797 & Coal & 7.80 & 161 & 11.8 & 69.3 & 17.0 & 232 & 0.05 & 13.6 & 169 & 433 \\
\hline 2886 & Coal & 13.9 & 187 & 9.50 & 72.4 & 13.1 & 259 & 0.07 & 19.7 & 201 & 433 \\
\hline \multirow[t]{2}{*}{2938} & Coal & 14.9 & 169 & 9.10 & 64.6 & 14.1 & 262 & 0.08 & 18.6 & 184 & 433 \\
\hline & Mudstone & 5.60 & 70.8 & 4.10 & 24.9 & 16.5 & 284 & 0.07 & 17.2 & 76.4 & 435 \\
\hline \multirow[t]{2}{*}{3158} & Coal & 21.1 & 200 & 9.60 & 70.2 & 13.7 & 286 & 0.10 & 20.9 & 222 & 437 \\
\hline & Mudstone & 7.10 & 77.3 & 4.10 & 23.6 & 17.4 & 328 & 0.08 & 18.8 & 84.4 & 437 \\
\hline \multirow[t]{2}{*}{3313} & Coal & 21.0 & 187 & 8.20 & 77.2 & 10.6 & 242 & 0.10 & 22.8 & 208 & 442 \\
\hline & Mudstone & 7.10 & 66.2 & 4.20 & 27.7 & 15.2 & 239 & 0.10 & 15.8 & 73.3 & 443 \\
\hline \multirow[t]{2}{*}{3469} & Coal & 16.4 & 126 & 16.4 & 63.7 & 25.7 & 198 & 0.12 & 7.69 & 143 & 440 \\
\hline & Mudstone & 5.60 & 57.6 & 3.50 & 20.1 & 17.4 & 287 & 0.09 & 16.5 & 63.2 & 443 \\
\hline 3575 & Coal & 21.4 & 178 & 5.00 & 88.9 & 5.62 & 200 & 0.11 & 35.5 & 199 & 450 \\
\hline \multirow[t]{2}{*}{3578} & Coal & 21.4 & 172 & 9.10 & 79.8 & 11.4 & 216 & 0.11 & 18.9 & 194 & 451 \\
\hline & Mudstone & 5.90 & 53.4 & 3.30 & 21.1 & 15.6 & 253 & 0.10 & 16.2 & 59.3 & 449 \\
\hline \multirow[t]{2}{*}{3734} & Coal & 19.8 & 158 & 9.50 & 72.6 & 13.1 & 217 & 0.11 & 16.6 & 178 & 451 \\
\hline & Mudstone & 6.60 & 59.3 & 4.60 & 26.4 & 17.4 & 225 & 0.10 & 12.9 & 65.9 & 449 \\
\hline 3749 & Coal & 19.2 & 156 & 4.10 & 81.9 & 5.00 & 191 & 0.11 & 38.0 & 175 & 454 \\
\hline \multirow[t]{2}{*}{3871} & Coal & 20.6 & 144 & 8.70 & 74.1 & 11.7 & 194 & 0.13 & 16.5 & 164 & 453 \\
\hline & Mudstone & 7.50 & 56.2 & 3.70 & 27.5 & 13.5 & 204 & 0.12 & 15.2 & 63.7 & 453 \\
\hline \multirow[t]{2}{*}{3962} & Coal & 20.7 & 129 & 8.40 & 77.0 & 10.9 & 167 & 0.14 & 15.3 & 149 & 457 \\
\hline & Mudstone & 6.30 & 42.6 & 2.90 & 22.9 & 12.7 & 186 & 0.13 & 14.7 & 48.9 & 458 \\
\hline \multirow[t]{2}{*}{4109} & Coal & 10.1 & 125 & 9.60 & 75.5 & 12.7 & 165 & 0.13 & 13.0 & 144 & 459 \\
\hline & Mudstone & 4.20 & 31.8 & 2.30 & 16.2 & 14.2 & 196 & 0.12 & 13.8 & 36.0 & 459 \\
\hline
\end{tabular}

values that range from 0.39 to $1.15 \%$. PY is defined as the summation of $S_{1}$ and $S_{2}$, which contain values ranging from 36 to $221.5 \mathrm{mg} \mathrm{HC} / \mathrm{g}$ TOC for the Taratu Formation. The ratio between $S_{1}$ and PY makes up the PI, where it is the proportion of the amount of free hydrocarbons already generated to the total amount of hydrocarbon that the organic matter is capable of generating. This parameter can be used to measure source rock thermal maturity (Peters 1986; Shalaby et al. 2011, 2012a, b; El Nady et al. 2015; Qadri et al. 2016; Jumat et al. 2018; Osli et al. 2018). In this study, PI values range from 0.0642 to 0.117 .

The origin of hydrocarbon generated by the Taratu source rock has been examined through a cross-plot of $S_{1}$ versus TOC (Fig. 3). The graph shows that the hydrocarbon of the Taratu Formation is uncontaminated and was created in situ. Hydrocarbon generation potential can also be investigated using the graph of PY versus TOC (Fig. 4). This cross-plot shows that all coal samples are characterized by higher TOC and PY regardless of its age, as compared to the corresponding samples from mudstone.

\section{Type of organic matter}

A combination of several pyrolysis results and their derivations are applied to determine the type of organic matter and hydrocarbon generated of the Taratu Formation source rock. The relationship between $S_{2}$ and TOC will investigate the type of organic matter present (Fig. 5; Langford and BlancValleron 1990). Kerogen type II-III is the most dominant kerogen type in this well from both coals and mudstone samples from the Late Cretaceous to Paleocene. Few gas-prone kerogen type III is detected from the coal samples.

The modified Van Krevelen diagram is functions to demonstrate the type of kerogen present by correlating $\mathrm{HI}$ and $\mathrm{OI}$ of a source rock. Figure 6 shows that both coal and mudstone samples have the same range of values of HI (165-327.5 mg 
Fig. 3 A cross-plot of $S_{1}$ versus total organic carbon (TOC) to indicate the origin of hydrocarbon in the Taratu Formation (Fakhri et al. 2013)
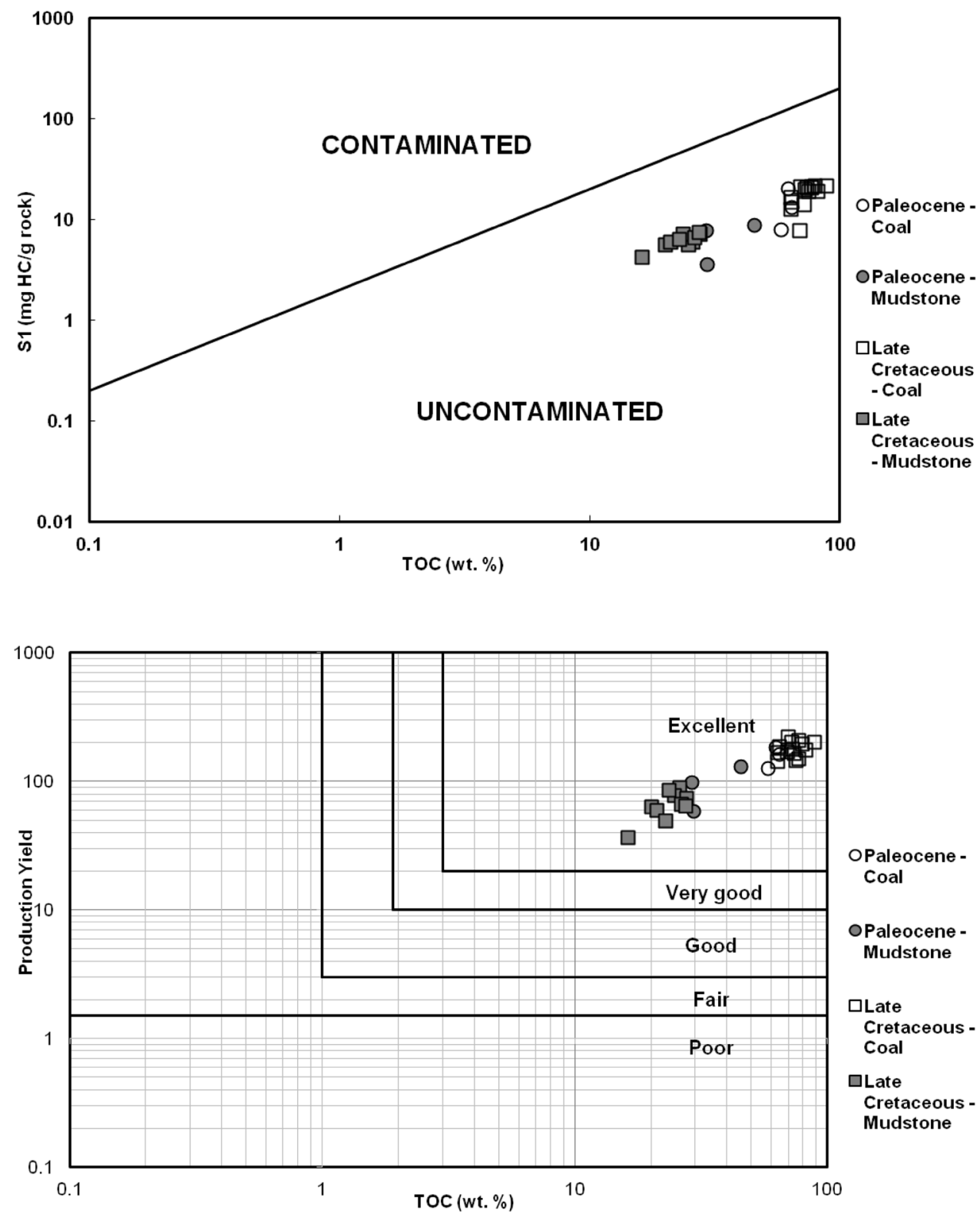

Fig. 4 A cross-plot of production yield (PY) versus total organic carbon (TOC) to exhibit the generating potential of the Taratu Formation
$\mathrm{HC} / \mathrm{g}$ TOC) and OI (5-25.7 $\mathrm{mg} \mathrm{CO}_{2} / \mathrm{g}$ TOC), with no sharp difference between both lithologies. For this reason, the Van Krevelen diagram thus shows the dominance of kerogen type II-III in the Taratu Formation, which is in a good agreement with Fig. 5.

\section{Thermal maturity and hydrocarbon generation potential}

Thermal maturities of the Taratu Formation in this study are measured using $T_{\text {max }}$, measured vitrinite reflectance $\left(\% R_{\mathrm{o}}\right)$ and PI. Source rocks with more evolved organic matter will generate higher $T_{\max }$ values, illustrating a more thermally mature state (Barker 1974; Espitalié 1986).
A cross-plot between $T_{\max }$ and $\mathrm{HI}$ in Fig. 7 shows that the thermal maturity of the Taratu source rock increases with age, regardless of lithology. Both Paleocene-aged coal and mudstone samples lie within the immature window as the $T_{\text {max }}$ values range between 420 to $426{ }^{\circ} \mathrm{C}$. $T_{\max }$ values for source rock samples from the Late Cretaceous for both lithologies gradually increase from 429 to $459{ }^{\circ} \mathrm{C}$ with increasing depth, thus located in the mature oil window where oil and gas generation has commenced. Few data points from the Late Cretaceous are detected in the condensate wet gas zone. Therefore, Fig. 7 shows that the younger, Paleoceneaged Taratu Formation comprises only kerogen type II-III while the older Cretaceous-aged formation is capable of generating gas, as it has become more thermally mature with time. It can thus be concluded that the age with depth 
Fig. 5 A cross-plot of $S_{2}$ versus total organic carbon (TOC) to identify the type of hydrocarbon produced from both Paleocene and Cretaceous in well Tara-1 (Langford and Blanc-Valleron 1990)

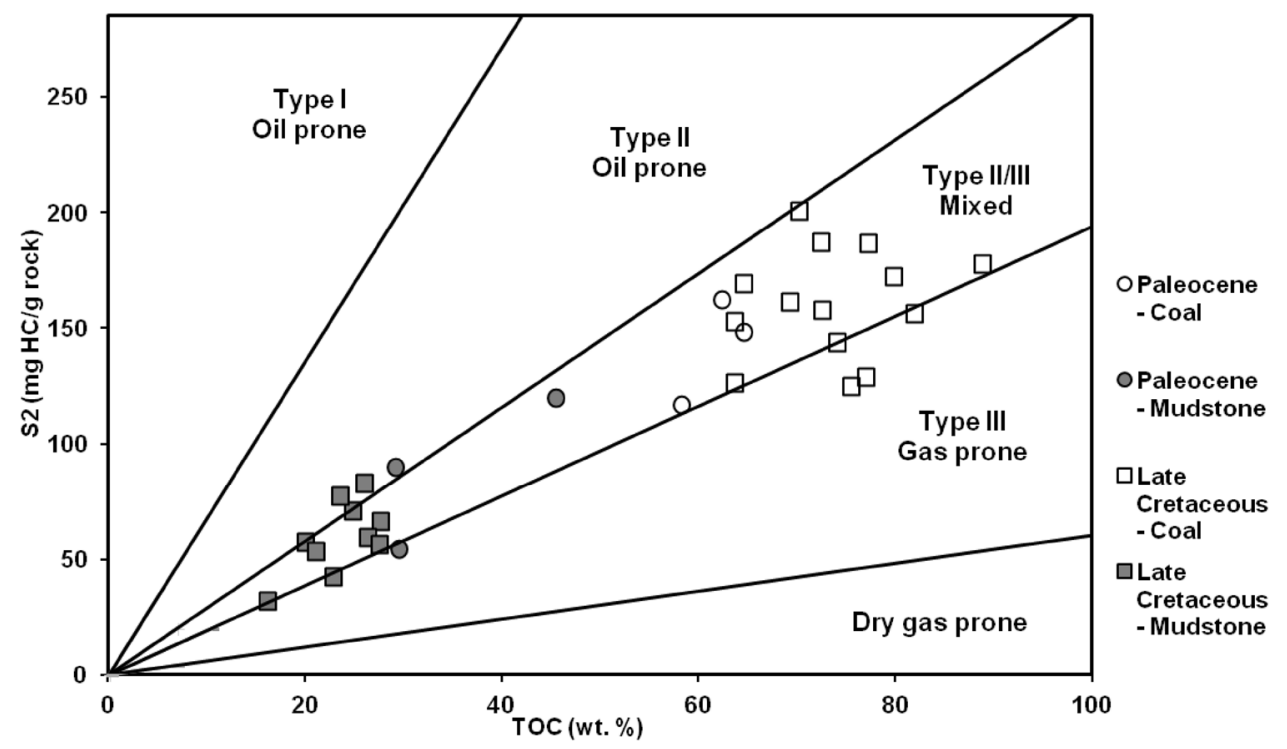

Vitrinite reflectance is a maturity-measuring parameter for coals or organic matter developed in continental plants, at which an increase in vitrinite reflectance value reflects an increasing amount of thermally mature organic matter (Price and Barker 1985; Stach et al. 1982). Because vitrinite reflectance is dependent on the maturity of organic matter, which is consequently affected by depth, this parameter is also similarly different between Paleocene and Late Cretaceous source rocks of the Taratu Formation.

All of the Paleocene source rock samples contain vitrinite reflectance values of $0.4 \%$ to than $0.65 \%$, while those belonging to Late Cretaceous age ranges from 0.65 to $1.15 \%$ (Table 2). Therefore, Cretaceous source rocks are within the mature oil and condensate wet gas windows due to their higher vitrinite reflectance values. Vitrinite reflectance can also be plotted with $T_{\max }$ to identify the state of thermal maturity for the organic matter (Qadri et al. 2016; Jumat et al. 2018). Both parameters are plotted together in Fig. 8 to show the change in thermal maturity of the Taratu Formation, from Paleocene to the Late Cretaceous.

PI values between 0.1 and 0.4 are considered a thermally mature source rock. A thermally immature source rock is characterized by PI values less than 0.1 , and an over-mature source rock is indicated by PI values of more than 0.4 (Peters 1986). PI is correlated with $T_{\max }$ in Fig. 9, which shows a thermally immature source rock for Paleocene samples and a thermally mature source rock with higher $T_{\max }$ and PI for samples belonging to the Late Cretaceous. Figures 10 and 11 show how depth affects the thermal maturity of the Taratu source rock. Samples from shallower depths are most likely

\section{OPaleocene -
Coal \\ OPaleocene - \\ 口Late \\ $\square$ Late
Cretaceous - \\ Mudstone}

and time are the controlling factors to maturity of source rock samples from the Taratu Formation regardless of its lithology.
Fig. 6 A cross-plot of hydrogen index (HI) versus oxygen index (OI)

in the modified Van Krevelen diagram shows the type of kerogen
available in the Taratu source rock (Espitalié et al. 1985)

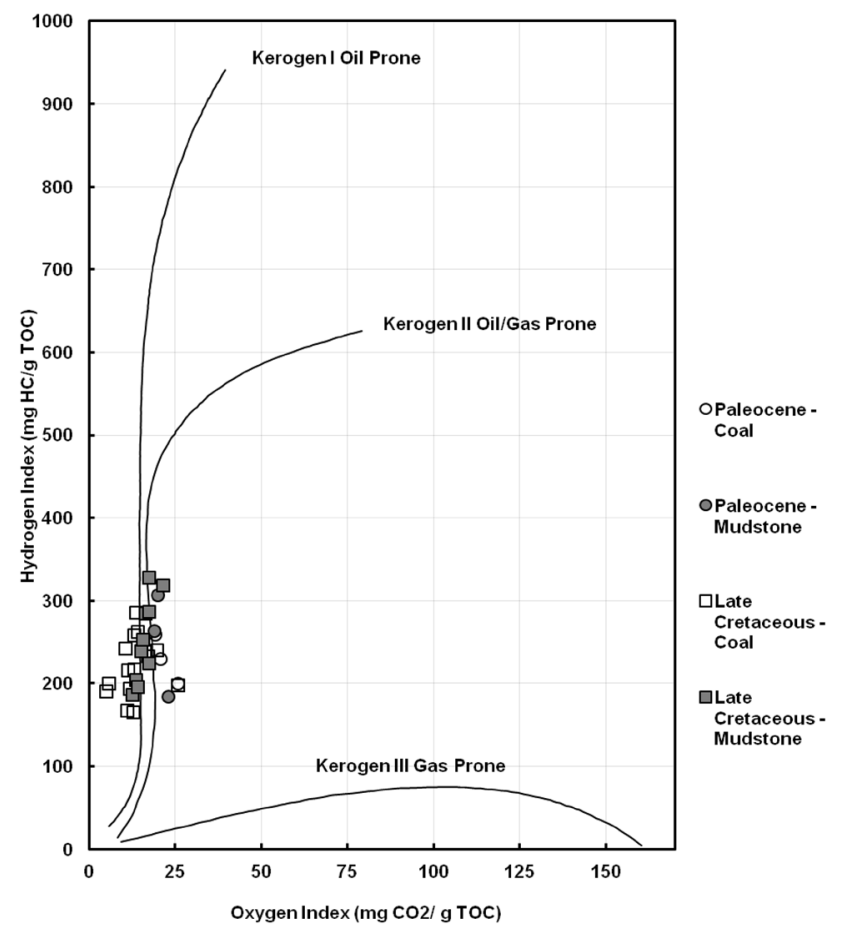


Fig. 7 A cross-plot of hydrogen index (HI) versus maximum pyrolysis temperature $\left(T_{\max }\right)$ to indicate source rock maturity

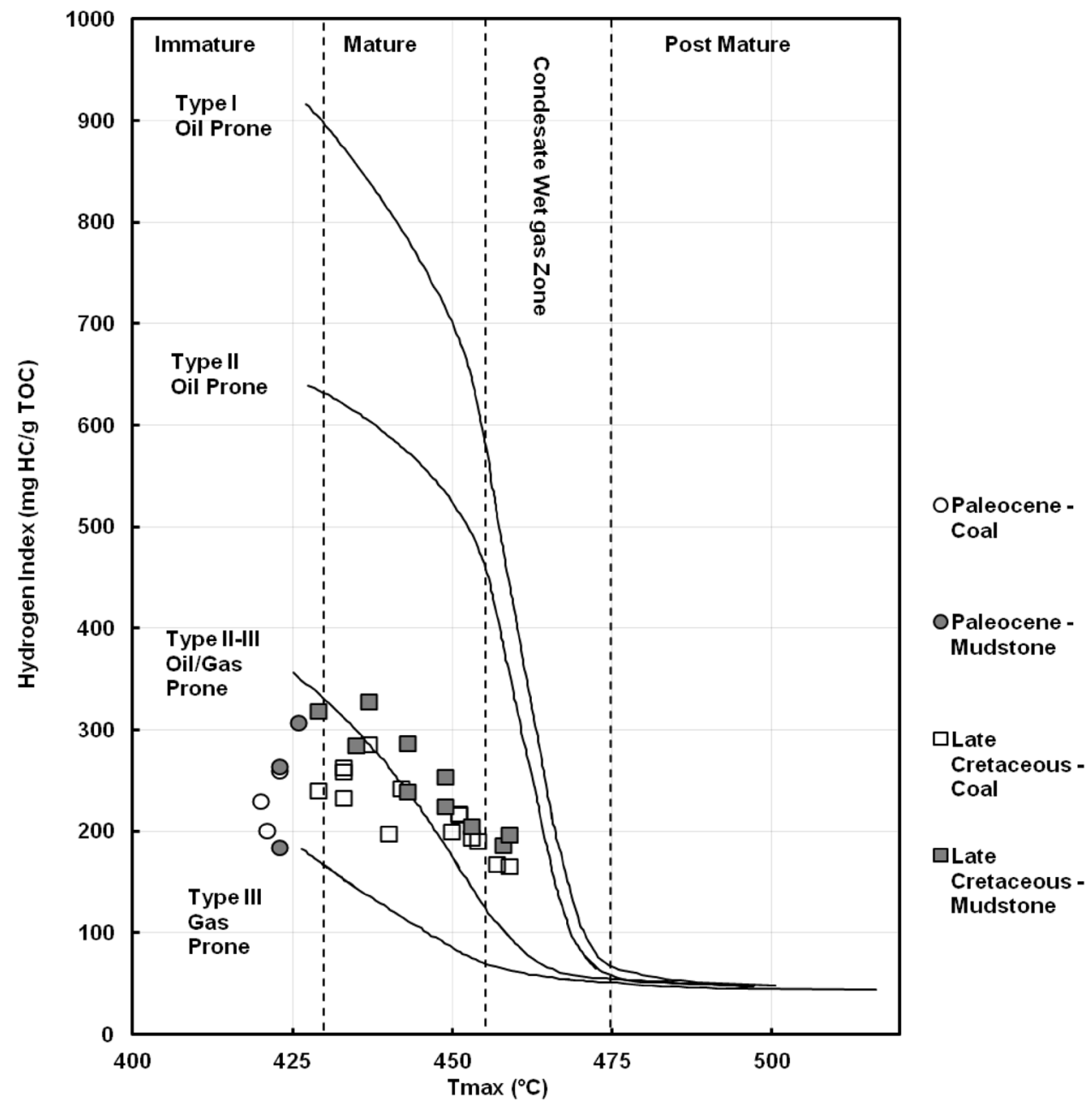

thermally immature, while the maturity level in terms of both $T_{\max }$ and $\% R_{\mathrm{o}}$ as increasing with increasing depth.

\section{Burial history and basin modeling}

\section{Subsidence and burial history}

One-dimensional basin model has been constructed by applying the PetroMod software. This is done to comprehend the burial history, thermal maturity history, timing and depth of hydrocarbon generation of the Taratu Formation.

In Tara-1 well, the Late Cretaceous Hoiho Formation overlies the metamorphic basement. This Formation was deposited from 100.5 to $95.2 \mathrm{Ma}$, producing a coaly shale of $83 \mathrm{~m}$ thick (Fig. 12). This is succeeded by the deposition of the coaly shale Taratu Formation until 71.8 Ma, and has a present thickness of $2165 \mathrm{~m}$. Wickliffe Formation overlies the Taratu Formation, and it was deposited from 71.8 to $67.7 \mathrm{Ma}$, to produce a $133 \mathrm{~m}$ thick layer of shale. From
67.7 to 34.5 Ma, the Laing Formation was deposited in three sequences with its own lithological characteristics. From 34.5 to $15.9 \mathrm{Ma}$, limestone of the Penrod Formation was deposited and has a current thickness of $508 \mathrm{~m}$ (Fig. 12). From 15.9 Ma to the recent time, recent sediments are deposited. All the parameters required to generate the 1-D model for well Tara- 1 is summarized in Table 3.

\section{Data calibration and thermal history}

According to Pandey (1981), heat flows in the Great South Basin are high, with values ranging from 87.2 to $163.8 \mathrm{~mW} /$ $\mathrm{m}^{2}$, which is attributable to the presence of young volcanism. These young volcanic bodies take in the form of intrusions and are located above the basement. Seismic evidence also suggests the presence of a large batholith within the basement in one of the wells in the basin (Hunt International Petroleum Company 1978). 
Table 2 Vitrinite reflectance values from Tara-1 well used in thermal maturity measure used in this study

\begin{tabular}{ll}
\hline Depth $(\mathrm{m})$ & $\% R_{\mathrm{o}}$ \\
\hline 945 & 0.34 \\
1189 & 0.39 \\
1341 & 0.35 \\
1585 & 0.38 \\
1676 & 0.37 \\
1859 & 0.37 \\
2012 & 0.46 \\
2438 & 0.45 \\
2469 & 0.53 \\
2591 & 0.55 \\
2797 & 0.55 \\
2835 & 0.58 \\
3048 & 0.60 \\
3158 & 0.76 \\
3167 & 0.82 \\
3313 & 0.87 \\
3353 & 0.88 \\
3575 & 0.95 \\
3578 & 0.99 \\
3578 & 0.98 \\
3734 & 0.98 \\
3749 & 1.04 \\
3871 & 1.06 \\
3962 & 1.12 \\
4109 & 1.15 \\
\hline & \\
&
\end{tabular}

However, a more recent paper written by Godfrey et al. (2001) stated that the background heat flow in the Great South Basin is approximately $60 \mathrm{~mW} / \mathrm{m}^{2}$, similar to that of Taranaki Basin, thus this research will utilize this heat flow value. In a calibration between modeled and measured temperature values, a generally good fit between both is achieved (Fig. 13).

The measurement of vitrinite reflectance values does not usually reflect true values as they are often subjected to suppression due to several factors. Factors that can contribute to vitrinite reflectance suppression as suggested by Mukhopadhyay (1994), including difference in lithology, peryhydrous vitrinite formation, presence of bitumen in source rocks as indicated by $S_{1}$ values, abundance of liptinite macerals, intensity of bacterial activity, and contamination of samples.

Specifically for New Zealand coals, Quick (1992) indicated that vitrinite reflectance suppression took place due to the presence of sulfate-reducing bacteria. A cross-plot between sulfur concentration (\%) and vitrinite reflectance $\left(\% R_{\mathrm{o}}\right)$ in Fig. 14 indicates that a negative relationship has been deduced from both parameters used. This may confirm the hypothesis that vitrinite reflectance values in this study have been subjected to suppression due to the presence of sulfate-reducing elements, therefore it must be taken into consideration.

For these reasons, all vitrinite reflectance values provided for this research must be corrected to get the true values and to avoid complications during calibration in PetroMod software. In this research, several research works have been considered for better performance in the correction of vitrinite reflectance values, such as by Lo (1993), Quick (1992), and Mukhopadhyay (1994). After correction, a best fit of the modeled and measured vitrinite reflectance values has been obtained (Fig. 15).
Fig. 8 A cross-plot of maximum pyrolysis temperature $\left(T_{\max }\right)$ versus vitrinite reflectance $\left(\% R_{\mathrm{o}}\right)$ to indicate source rock thermal maturity

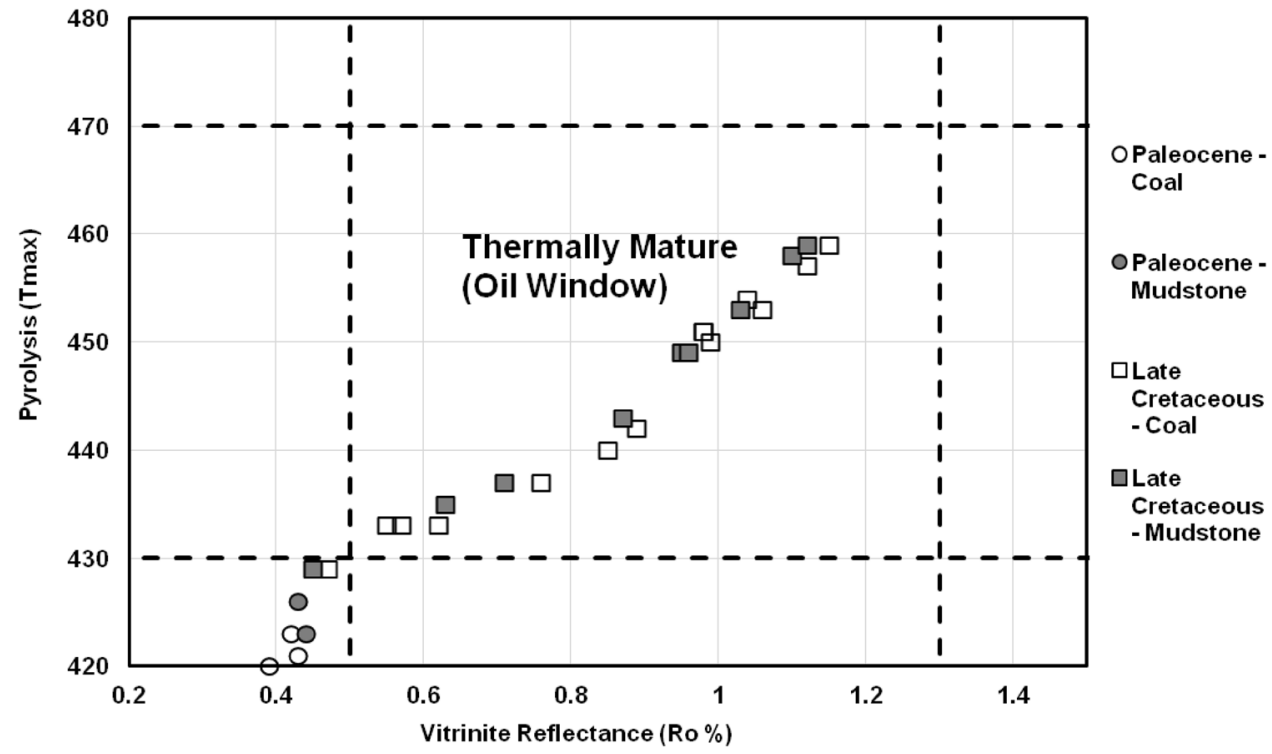

(1) 
Fig. 9 A cross-plot of maximum pyrolysis temperature $\left(T_{\max }\right)$ versus production index $(\mathrm{PI})$ to identify source rock maturity

Fig. 10 A cross-plot of maximum pyrolysis temperature $\left(T_{\max }\right)$ versus depth to demonstrate the distribution of the parameter with increasing depth
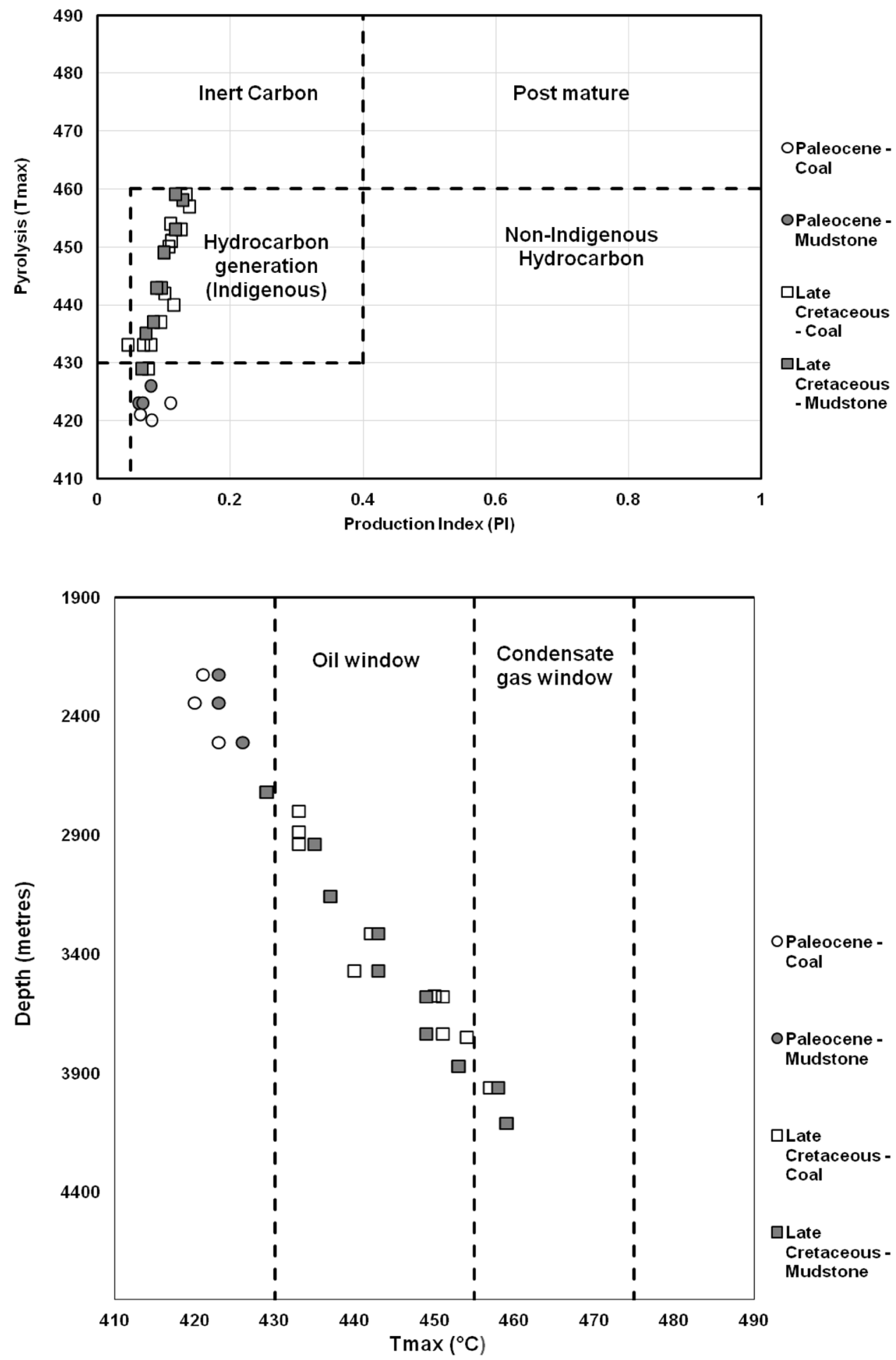

Timing of hydrocarbon generation and expulsion of the Taratu Formation

Exact timing and depth of hydrocarbon generation and expulsion for the Taratu Formation can be acquired through one-dimensional basin modeling through the application of the PetroMod software. This was done based on the formation temperature and maturation history (Qadri et al. 2016; Jumat et al. 2018). The top of oil window for the Taratu Formation in Tara-1 well was encountered $51 \mathrm{Ma}$ ago at $3100 \mathrm{~m}$ depth from the surface (Fig. 16). Maturity to generate gaseous hydrocarbon took place at a depth of $4132 \mathrm{~m}$, at $8 \mathrm{Ma}$ ago. 
Fig. 11 A cross-plot of vitrinite reflectance $\left(\% R_{\mathrm{o}}\right)$ versus depth to demonstrate the distribution of the parameter with increasing depth
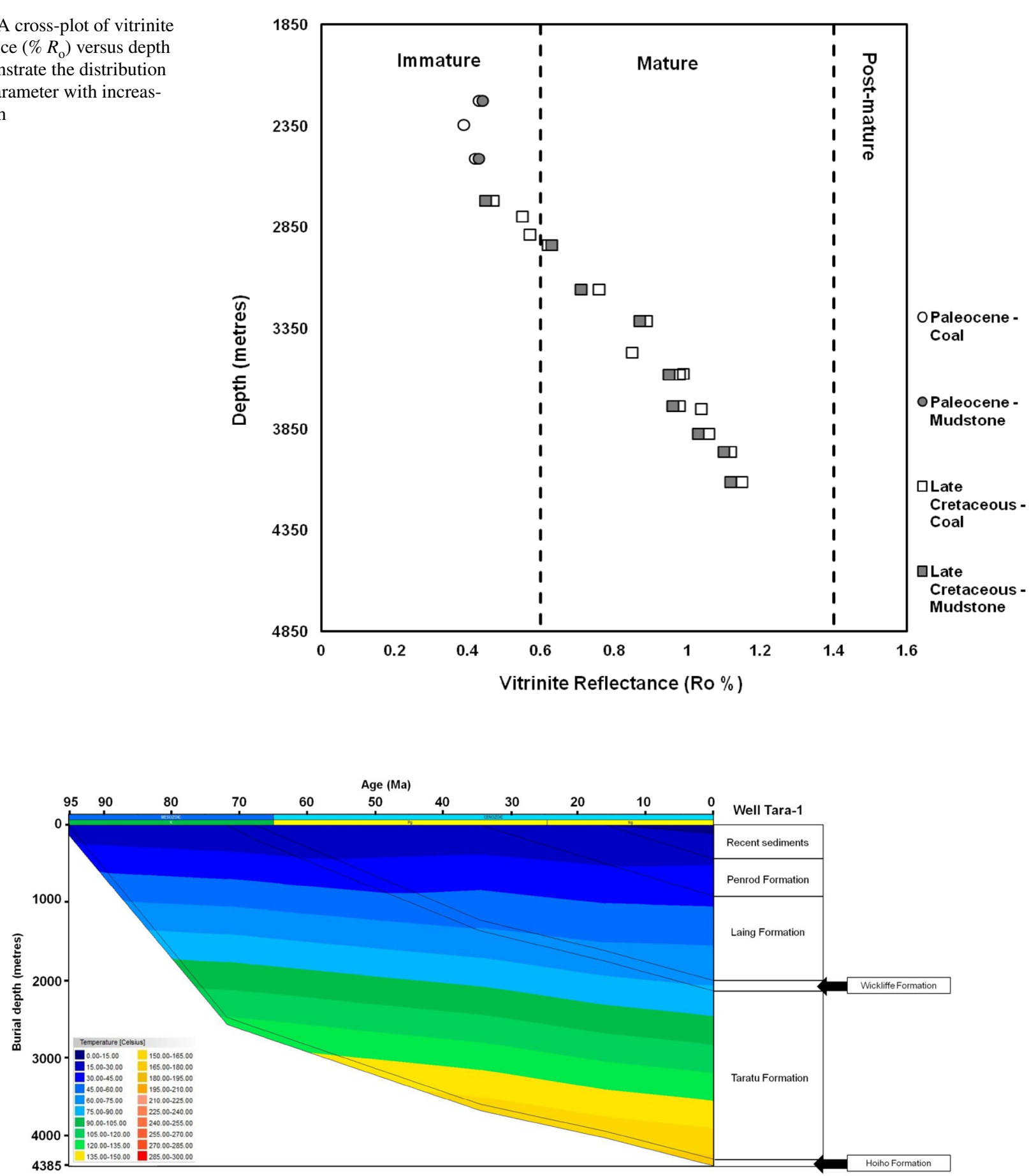

Fig. 12 Burial history with temperature variations for Tara-1 well

Hydrocarbon expulsion ratio model indicates the relative ratios between oil and gas generated by the source rock, which will indirectly indicate type of kerogen present and thermal maturity state of the source rock. As the formation consists of both kerogen type II-III and type III, there will be a mixture of both oil and gas in the hydrocarbon generation and this is reflected in Fig. 17. A transformation ratio of $12 \%$ shows that until the present, the Taratu Formation has expelled more oil relative to gas as the oil window has been reached in $51 \mathrm{Ma}$ upon thermal maturity. This also confirms the presence of kerogen type II/III and III present in the Taratu Formation. There was a rapid production of liquid hydrocarbon taking place from $68 \mathrm{Ma}$, with a concentration of $54 \mathrm{mg} \mathrm{HC} / \mathrm{g}$ TOC 
Table 3 Input parameters for 1-D modeling of Well Tara-1

Fig. 13 Calibration of measured and modeled temperature for Tara-1 well

\begin{tabular}{lrrrrll}
\hline Formation name & Age & Top $(\mathrm{m})$ & Bottom $(\mathrm{m})$ & Thickness (m) & Lithology & $\begin{array}{l}\text { Petroleum } \\
\text { system ele- } \\
\text { ments }\end{array}$ \\
\hline Recent sediments & $0-15.9$ & 0 & 442 & 442 & Shale & Overburden \\
Penrod & $15.9-34.5$ & 442 & 920 & 478 & Limestone & Overburden \\
Laing & $34.5-67.7$ & 920 & 2006 & 1086 & Shale and sand & Seal \\
Wickliffe & $67.7-71.8$ & 2006 & 2139 & 130 & Sand and shale & Reservoir \\
Taratu & $71.8-95.2$ & 2139 & 4304 & 2165 & Coaly shale & Source rock \\
Hoiho & $95.2-100.2$ & 4304 & 4387 & 83 & Coaly shale & Underburden \\
\hline
\end{tabular}

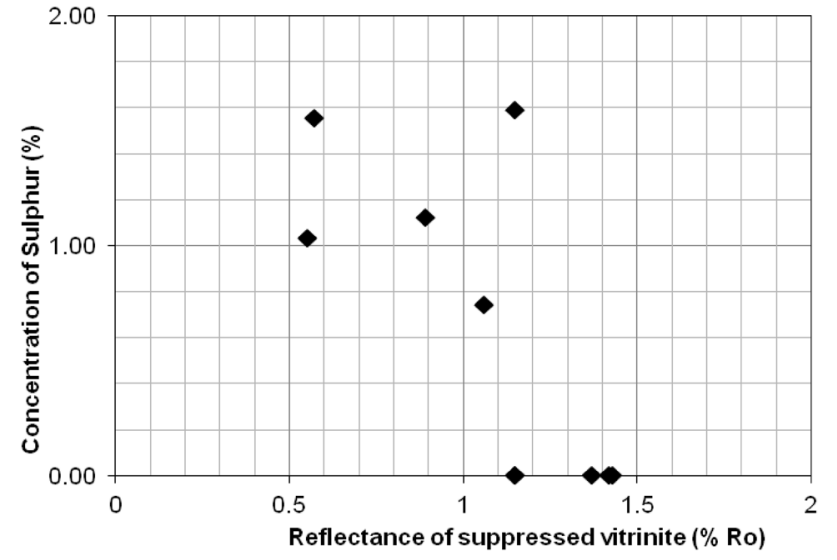

Fig. 14 Correlation between sulfur and $\% R_{\mathrm{o}}$ to show the relationship between both parameters
(Fig. 17). During the same time interval, gaseous hydrocarbon generation also simultaneously occurred with a present concentration of $12 \mathrm{mg} \mathrm{HC/g}$ TOC. However, as of present, generation of liquid and gaseous hydrocarbon has not reached their peaks.

\section{Conclusion}

The Taratu Formation in the Great South Basin of New Zealand is proven to be an excellent source rock in this study. The studied source rock samples collected from Tara-1 Well has two different ages: Paleocene and Cretaceous. Rock-Eval pyrolysis executed on these samples shows that higher readings of TOC and $S_{2}$ are detected in coal samples of both Paleocene and Late Cretaceous age relative to the mudstone samples. Regardless, the Taratu 
Fig. 15 Calibration of measured and modeled vitrinite reflectance values for Tara-1 well

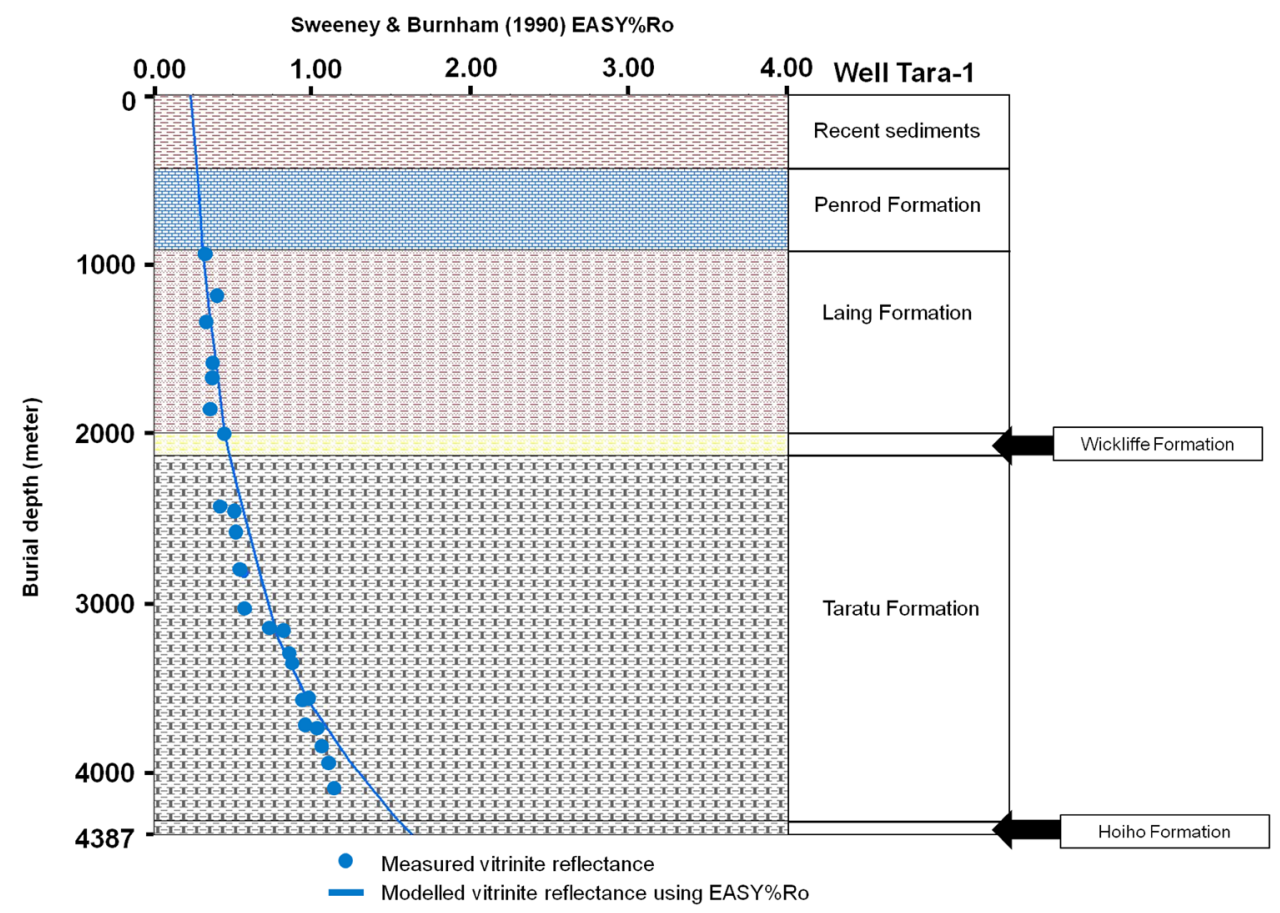

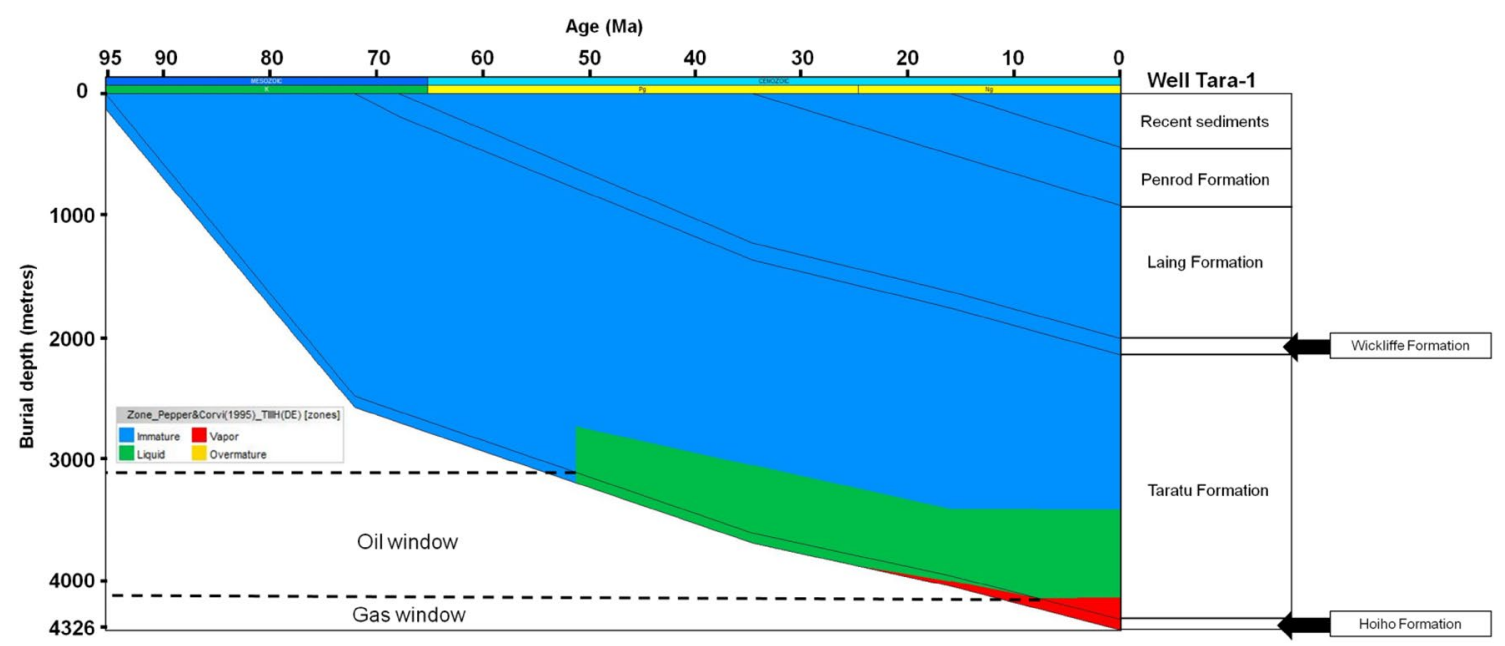

Fig. 16 Hydrocarbon generation model indicating oil, gas, and overmaturation windows for Tara-1 well

Formation is still considered a source rock of high quality and quantity, which generates kerogen type II-III and gasprone kerogen type III. Varying thermal maturity stages of the Taratu source rock is recorded; Paleocene source rocks located at relatively shallower depths are thermally immature based on the $T_{\max }, \mathrm{VR}$, and PI values. In turn, source rock belonging to the Late Cretaceous is thermally mature due to its relatively older age and greater depth of burial. One-dimensional basin modeling of Tara- 1 well allowed the understanding of burial and thermal histories of the Taratu Formation. An excellent fit between measured and modeled values for subsurface temperature and vitrinite reflectance are obtained after making the necessary adjustments, indicating a good data quality is used in this study. 
Fig. 17 Hydrocarbon multicomponent and transformation ratios for Tara-1 well

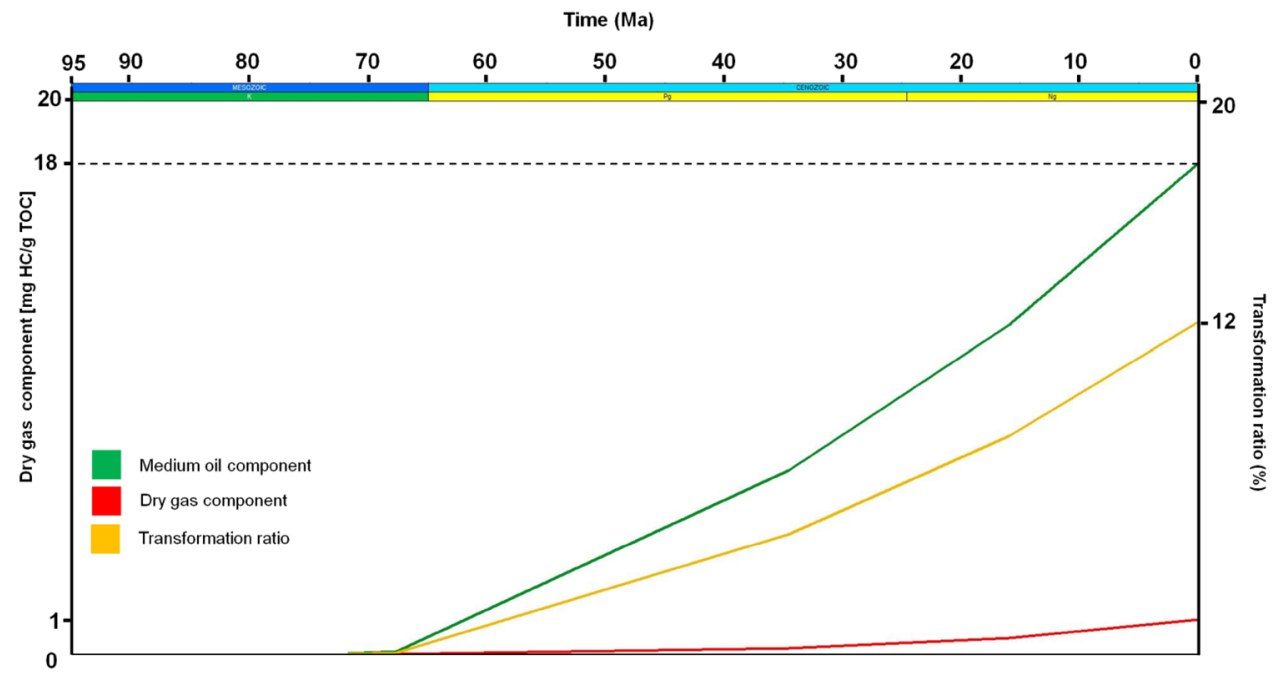

Top of oil and gas generative windows for the Formation are encountered at 51 and $8 \mathrm{Ma}$, respectively. In this study, all results are parallel and in agreement with each other.

Acknowledgements Many thanks to the New Zealand Petroleum and Minerals, Ministry of Business, Innovation and GNS Science for supplying data utilized in this study. The authors would like to express their gratitude to Universiti Brunei Darussalam for providing all facilities and assistance to undergo and publish the results of this research.

Open Access This article is distributed under the terms of the Creative Commons Attribution 4.0 International License (http://creativeco mmons.org/licenses/by/4.0/), which permits unrestricted use, distribution, and reproduction in any medium, provided you give appropriate credit to the original author(s) and the source, provide a link to the Creative Commons license, and indicate if changes were made.

\section{References}

Aitchison JC, Campbell JD, Stilwell JD (1993) Cretaceous/tertiary geology and macropaleontology of the Waianakarua District, North Otago, New Zealand. J R Soc NZ 23(1):43-54

ASTM (1975) Standard D-2797, microscopical determination of volume percent of physical components in a polished specimen of coal. ASTM, Philadelphia

Barker C (1974) Pyrolysis techniques for source-rock evaluation. AAPG Bull 58(11):2349-2361

Beggs JM (1993) Depositional and tectonic history of the Great South basin. In: Balance PF (ed) Sedimentary basins of the World, vol 2. Elsevier Science, Amsterdam, pp 93-107

Bullard EC (1947) The time necessary for a bore hole to attain temperature equilibrium. Geophys J Int 5(5):127-130

Constable RM, Langdale S, Allan TMH (2013) Development of a sequence stratigraphic framework in the Great South basin. In: Advantage NZ: 2013 petroleum conference. New Zealand Petroleum and Minerals, pp 1-21

Cook RA, Sutherland R, Zhu H (1999) Cretaceous-Cenozoic geology and petroleum systems of the Great South Basin. Institute of Geological and Nuclear Sciences, New Zealand, p 20

El Nady MM, Ramadan FS, Hammad MM, Lotfy NM (2015) Evaluation of organic matters, hydrocarbon potential and thermal maturity of source rocks based on geochemical and statistical methods: case study of source rocks in Ras Gharib oilfield, central Gulf of Suez, Egypt. Egypt J Pet 24(2):203-211

Espitalié J (1986) Use of $T_{\max }$ as a maturation index for different types of organic matter. Comparison with vitrinite reflectance. In: Burrus $\mathbf{J}$ (ed) Thermal modelling in sedimentary basins. Editions Technip, Paris, pp 475-496

Espitalié J, Deroo G, Marquis F (1985) Rock-Eval pyrolysis and its applications. Rev Inst Fr Pet 40(5):563-579

Evans PR (1982) Petroleum potential of New Zealand. J Pet Geol 5(1):89-96

Fakhri M, Tabatabei H, Amiri A (2013) Comparing the potential of hydrocarbon generation of Kazhdomi and Pabdeh formations in Bangestan Anticline (Zagros Basin) according to Rock-Eval pyrolysis data. J Earth Sci Clim Change 4:157

Godfrey NJ, Davey F, Stern TA, Okaya D (2001) Crustal structure and thermal anomalies of the Dunedin region, South Island, New Zealand. J Geophys Res Solid Earth 106(B12):30835-30848

Hunt International Petroleum Company (1978) Well completion report Hoiho-1C. P.P.L. 863. NZ Geol Surv. Petroleum Report No. 730

Jumat N, Shalaby MR, Islam MA (2017) An integrated source rock characterization using geochemical analysis and well logs: a case study of Taranaki Basin, New Zealand. Pet Coal 59(6):884-910

Jumat N, Shalaby MR, Haque AE, Islam MA, Hoon LL (2018) Geochemical characteristics, depositional environment and hydrocarbon generation modeling of the upper cretaceous Pakawau group in Taranaki Basin, New Zealand. J Pet Sci Eng 163:320-339

Killops SD, Cook RA, Sykes R, Boudou JP (1997) Petroleum potential and oil-source correlation in the Great South and Canterbury Basins. NZ J Geol Geophys 40:405-423

Killops S, Walker P, Wavrek D (2001) Maturity-related variations in the bitumen compositions of coals from Tara- 1 and Toko- 1 wells. NZ J Geol Geophys 44(1):157-169

Killops SD, Mills N, Johansen PE (2008) Pyrolytic assessment of oil generation and expulsion from a suite of vitrinite-rich New Zealand coals. Org Geochem 39(8):1113-1118

King PR (2000) Tectonic reconstructions of New Zealand: 40 Ma to the present. NZ J Geol Geophys 43(4):611-638

Laird MG, Bradshaw JD (2004) The break-up of a long-term relationship: the Cretaceous separation of New Zealand from Gondwana. Gondwana Res 7(1):273-286

Langford FF, Blanc-Valleron MM (1990) Interpreting Rock-Eval pyrolysis data using graphs of pyrolizable hydrocarbons vs. total organic carbon (1). AAPG Bull 74(6):799-804 
Lo HB (1993) Correction criteria for the suppression of vitrinite reflectance in hydrogen-rich kerogens: preliminary guidelines. Org Geochem 20(6):653-657

McMillan SG, Wilson GJ (1997) Allostratigraphy of coastal south and east Otago: a stratigraphic framework for interpretation of the Great South Basin, New Zealand. NZ J Geol Geophys 40(1):91-107

Mukhopadhyay PK (1994) Petrographic and molecular characterization and its applications to basin modeling. In: Mukhopadhyay PK, Dow WG (eds) Vitrinite reflectance as a maturity parameter: applications and limitations. American Chemical Society, Washington DC, pp 1-19

New Zealand Petroleum and Minerals (2014) New Zealand petroleum basins. Ministry of business, innovation and employment. New Zealand Petroleum and Minerals

Osli LN, Shalaby MR, Islam MA (2018) Characterization of source rocks and depositional environment, and hydrocarbon generation modeling of the Cretaceous Hoiho Formation, Great South Basin, New Zealand. Pet Coal 60(2):255-275

Pandey OP (1981) Terrestrial heat flow in the North Island of New Zealand. J Volcanol Geotherm Res 10(4):309-316

Pepper AS, Corvi PJ (1995) Simple kinetic models of petroleum formation. Part I: oil and gas generation from kerogen. Mar Pet Geol 12(3):291-319

Peters KE (1986) Guidelines for evaluating petroleum source rock using programmed pyrolysis. AAPG Bull 70(3):318-329

Peters KE, Cassa MR (1994) Applied source-rock geochemistry. In: Magoon LB, Dow WG (ed) The petroleum system-from source to trap, vol 60. AAPG Mem., pp 93-120

Peters KE, Nelson PH (2012) Criteria to determine borehole formation temperatures for calibration of basin and petroleum system models. In: Harris NB, Peters KE (eds) Analyzing the thermal history analysis of sedimentary basin: methods and case studies. SEPM Special Publication, pp 5-16

Price LC, Barker CE (1985) Suppression of vitrinite reflectance in amorphous rich kerogen - a major unrecognized problem. J Pet Geol 8(1):59-84

Qadri ST, Shalaby MR, Islam MA, Hoon LL (2016) Source rock characterization and hydrocarbon generation modeling of the Middle to Late Eocene Mangahewa Formation in Taranaki Basin, New Zealand. Arab J Geosci 9(10):8-9

Quick JC (1992) Fluorometric analysis relationships with reflectance, weathering, and thermoplastic behavior. The Society of Organic Petrology

Raine JI, Strong CP, Wilson GJ (1993) Biostratigraphic revision of petroleum exploration wells, Great South Basin, New Zealand. IGNS Science Report 93/32, Institute of Geological and Nuclear Sciences, Lower Hutt, New Zealand
Schiøler P, Rogers K, Sykes R, Hollis CJ, Ilg B, Meadows D, Roncaglia L, Uruski C (2009) Palynofacies, organic geochemistry and depositional environment of the Tartan Formation (Late Paleocene), a potential source rock in the Great South Basin, New Zealand. Mar Pet Geol 27(2):351-369

Shalaby MR, Hakimi MH, Abdullah WH (2011) Geochemical characteristics and hydrocarbon generation modelling of the Jurassic source rocks in the Shoushan Basin, north Western Desert, Egypt. Mar Pet Geol 28(9):1611-1624

Shalaby MR, Hakimi MH, Abdullah WH (2012a) Modeling of gas generation from the Alam El-Bueib formation in the Shoushan Basin, northern Western Desert of Egypt. Int J Earth Sci 102(1):319-332

Shalaby MR, Hakimi MH, Abdullah WH (2012b) Organic geochemical characteristics and interpreted depositional environment of the Khatatba Formation, northern Western Desert, Egypt. AAPG Bull 96:2019-2036

Stach E, Mackowsky M-Th, Teichmüller M, Taylor GH, Chandra D, Teichmüller R (1982) Stach's textbbok of coal petrology, 3rd edn. Gebruder Borntraeger, Berlin, pp 1-535

Sykes R, Suggate RP, Funnell RH, Boudou JP, Killops SD, Cook RA, Newman J (1998) Petroleum generation and expulsion from coals and coaly shales in Tara-1, Great South Basin, New Zealand: facies controls, maturity thresholds and expulsion history. In: International conference on coal seam gas and oil, p 22

Tissot BP, Welte DH (1984) Petroleum formation and occurrence: a new approach to oil and gas exploration. Springer, Berlin, p 538

Uruski CI, Baillie P (2001) Petroleum potential of New Zealand's deepwater basins. In: PESA Eastern Australasia basins symposium, pp 151-158

Waples DW, Ramly M (1994) A simple statistical method for correcting and standardizing heat flows and subsurface temperatures derived from log and test data. Bull Geol Soc Malays Spec Publ 37:253-267

Waples DW, Ramly M (2001) A statistical method for correcting logderived temperatures. Pet Geosci 7(3):231-240

Wilson GJ, McMillan SG (1996) Late Cretaceous-Tertiary stratigraphic sections of Coastal Otago, South Island New Zealand: a summary of biostratigraphic and lithostratigraphic data. IGNS Science Report 96/39, Institute of Geological and Nuclear Sciences, Lower Hutt, New Zealand

Publisher's Note Springer Nature remains neutral with regard to jurisdictional claims in published maps and institutional affiliations. 